\title{
HUBUNGAN STATUS OBESITAS TERHADAP HIPERTENSI DI PUSKESMAS SUNGKAI KABUPATEN BANJAR
}

\author{
Zaleha*, Alfian Yusuf ** \\ *Puskesmas Sungkai, Kabupaten Banjar Jl. A.Yani Km 75 Email: zaleha_gizi@yahoo.com \\ **Poltekkes Banjarmasin Jurusan Gizi Jl Belitung Darat No. 118 A Banjarmasin, Email: \\ alfianhanafi67@yahoo.com
}

\begin{abstract}
Hypertension is becoming more prevalent in Indonesia. The risk of Hypertension increase with the development of obesity. A limited number of studies in Indonesia have examined relationship between obesity indicator and hypertension. The objective of the study conducted to know related between several obesity indicator and hypertension of patients at Sungkai Public Health Center in Banjar District. The study was observasional analityc with case control matched study. Subjects this study consisted of 60 subjects that were collected consecutively and devided into two group, case and control with comparison case and control 1 : 1. Blood pressure. Body Mass Index (BMI), Waist Circumference (WC) and Waist to Hip Ratio (WHR) were obtained, Chi Square Test or Fisher Exact Test was used to bivariate analitytic with $\alpha=0,05$. The Odds Ratio (OR) was calculated to predict the risk of each obesity indicator to hypertension. This study showed that BMI was significantly related with essensial hypertension in bivariate analysis $(\mathrm{OR}=3,1)$. The nonsignificant correlation $(\mathrm{p}>0,05)$ identified for Waist Circumference and Waist Hip Ratio. Obesity indicator related to essential hypertension of patients at Sungkai Public Health Center in Banjar District was BMI
\end{abstract}

\begin{abstract}
Abstrak: Hipertensi menjadi lebih umum dalam risiko Indonesia. Kenaikan Hipertensi dengan perkembangan obesitas. Studi terbatas di Indonesia telah meneliti hubungan antara indikator obesitas dan hipertensi. Tujuan dari penelitian yang dilakukan untuk mengetahui keterkaitan antara indikator obesitas dan hipertensi beberapa pasien di Pusat Kesehatan Masyarakat di Kecamatan Sungkai Banjar. Penelitian ini adalah analitik observasional dengan studi kasus kontrol. Subjek penelitian ini terdiri dari 60 mata pelajaran yang dikumpulkan secara berurutan dan dibagi menjadi dua, kelompok kasus dan kontrol dengan perbandingan kasus dan kontrol 1: 1. Tekanan darah. Body Mass Index (BMI), Lingkar Pinggang (WC) dan Pinggang Terhadap Hip (WHR) diperoleh, Chi Square Test atau Uji Fisher Exact digunakan untuk analitytic bivariat dengan $\alpha=0,05$. Rasio Odds (OR) dihitung untuk memprediksi risiko masing-masing indikator obesitas untuk hypertension. Penelitian menunjukkan bahwa BMI secara signifikan berhubungan dengan hipertensi essensial dalam analisis bivariat $(\mathrm{OR}=3,1)$. Korelasi tidak signifikan $(\mathrm{p}>0,05)$ diidentifikasi untuk Lingkar Pinggang dan Rasio Pinggang Panggul. Obesitas indikator yang berhubungan dengan hipertensi esensial pasien di Pusat Kesehatan Masyarakat di Sungkai Kabupaten Banjar adalah BMI
\end{abstract}

Kata Kunci: Hipertensi, Obesitas, BMI, WHR, lingkar pinggang

Hipertensi sampai saat ini masih tetap menjadi masalah karena beberapa hal, antara lain meningkatnya prevalensi hipertensi serta adanya penyakit penyerta dan komplikasi yang dapat meningkatkan morbiditas dan mortalitas (Aru,et al, 2006). Hipertensi yang merupakan salah satu masalah kesehatan masyarakat yang penting, seringkali dijumpai tanpa gejala, relatif mudah diobati dan bila tidak diobati sering menimbulkan komplikasi. Hipertensi yang tidak terkendali, dalam jangka panjang berdampak timbulnya gangguan jantung
(75\%), stroke (15\%) dan gangguan fungsi ginjal (10\%), bahkan kematian mendadak, oleh karena itu hipertensi disebut juga the sillent killer. Penyakit ini juga dikenal sebagai heterogenous group of disease, karena dapat menyerang siapa saja dengan berbagai kelompok umur dan kelompok sosial ekonomi (Karyadi E., 2002).

Prevalensi Hipertensi diseluruh dunia diperkirakan 15-20\%. Sekitar 50 juta orang di Amerika Serikat memiliki tekanan darah yang membutuhkan pengobatan dan gam- 
baran yang sama terlihat di Uni Eropa (Beevers, D.G.,2002).

Berdasarkan hasil Survei faktor risiko penyakit kardiovaskular (PKV) oleh proyek WHO di Jakarta menunjukkan angka prevalensi hipertensi dengan tekanan darah 160/90 pada pria adalah $12,1 \%$ (2000). Pada wanita, angka prevalensi mencapai $12,2 \%$ (2000). Survei di pedesaan Bali (2004) menemukan prevalensi pria sebesar 46,2\% dan 53,9\% pada wanita. Prevalensi di Vietnam pada tahun 2004 mencapai 34,5\%, Thailand (1989) 17\%, Malaysia (1996) 29,9\%, Philippina (1993) 22\%, dan Singapura (2004) 24,\% (Depkes RI, 2008).

Prevalensi hipertensi di luar Jawa-Bali lebih besar dibandingkan dengan JawaBali, hal tersebut terkait erat dengan pola makan yang tinggi dengan konsumsi garam.(Karyadi E., 2002). Berdasarkan Hasil Riset kesehatan Dasar Provinsi Kalimantan selatan tahun 2010 diketahui bahwa Prevalensi Hipertensi pada penduduk 18 tahun ke atas berdasarkan hasil pengukuran tekanan darah adalah 39,6\%. Sedangkan prevalensi hipertensi untuk kabupaten Banjar adalah 39,1\%. dan berdasarkan studi pendahuluan yang dilakukan di Puskesmas Sungkai diketahui bahwa Hipertensi merupakan penyakit nomor 2 dari 10 penyakit terbanyak.

Hipertensi dapat disebabkan oleh berbagai faktor seperti obesitas, dislipidemia, stres, olahraga/aktivitas fisik, merokok, konsumsi alkohol berlebihan, konsumsi garam berlebihan dan diet yang tidak seimbang (Elvina K., 2002)

Obesitas terutama tipe sentral/abdominal sering dihubungkan dengan beberapa keadaan seperti diabetes melitus, hiperlipidemia, penyakit jantung, hipertensi, penyakit hepatobiliar dan peningkatan resiko mortalitas dan morbiditas. Swedish Obese Study (1999) mendapatkan kejadian hipertensi pada $13,6 \%$ populasi obesitas. Berat badan dan Indeks massa tubuh (IMT) berkorelasi langsung dengan dengan tekanan darah, terutama tekanan darah Sistolik. Resiko relatif untuk menderita hipertensi pada orang orang gemuk 5 kali lebih tinggi dibandingkan dengan seorang yang berat badannya normal. Fakta lain, penderita hipertensi ditemukan sekitar 20-33\% memiliki berat badan lebih (overweight). Studi lain yang menunjang, melaporkan bahwa distribusi lemak di dalam tubuh juga merupakan faktor yang penting dalam hubungannya dengan hipertensi, disbandingkan dengan jumlah lemak dalam tubuh itu sendiri.

Indikator yang biasa digunakan untuk mengukur deposit lemak terutama bagian perut ,digunakan pengukuran rasio Lingkar pinggang/lingkar panggul (waist to hip ratio) dan Waist circumference (Elvina K.2002). Dikatakan risiko tinggi bila memiliki WHR $\geq 0,95$ untuk laki-laki dan $\geq$ 0,85 untuk wanita, serta waist circumference $>102 \mathrm{~cm}$ untuk laki-laki dan >88 $\mathrm{cm}$ untuk wanita.Laki-laki memiliki resiko angka kejadian penyakit kardiovaskular yang lebih tinggi dibanding wanita, karena obesitas tipe sentral ini lebih banyak terjadi pada laki-laki dibanding wanita. Hal ini disebabkan adanya perbedaan distribusi lemak tubuh antara laki-laki dan wanita. Pada laki-laki distribusi lemak tubuh terutama pada daerah abdomen sedangkan wanita lebih banyak pada daerah gluteal dan femoral.

Perubahan berat badan juga merupakan salah satu faktor penting pada survival rate penderita hipertensi. Perubahan berat badan merupakan sebanyak $5 \mathrm{~kg}$ (meningkat ataupun menurun) pada kurun waktu 10-15 tahun akan meningkatkan angka mortalitas sebesar 1,5-2 kali lebih tinggi. Pada satu studi prospektif- epidemiologi didapatkan angka mortalitas penyakit kardiovaskular lebih rendah pada populasi dengan berat badan yang stabil selama kurun waktu tertentu. Pada obesitas biasanya sering didapatkan adanya fluktuasi peningkatan dan penurunan berat badan secara periodik ini akan meningkatkan resiko mortalitas pada obesitas (Sanif Edial, 2008).

Berdasarkan uraian di atas, maka peneliti ingin mengetahui apakah ada hubungan antara status obesitas (berdasarkan indikator IMT, lingkar pinggang dan rasio 
lingkar pinggang panggul) dengan hipertensi di Puskesmas Sungkai kabupaten Banjar karena penelitian sejenis belum pernah dilaksanakan di puskesmas Sungkai. Berdasarkan survey pendahuluan, sampai tanggal 28 Mei 2011 terdapat sebanyak 97 pasien baru dari 1975 kunjungan pasien dengan diagnosa Hipertensi Essensial di Poli Puskesmas Sungkai Kabupaten Banjar (Puskesmas Sungkai, 2011).

Tujuan dari penelitian ini adalah untuk mengetahui hubungan antara status obesitas (berdasarkan indikator IMT, lingkar pinggang dan rasio lingkar pinggang panggul) terhadap Hipertensi di puskesmas Sungkai kecamatan simpang Empat kabupaten Banjar.

\section{BAHAN DAN CARA}

Penelitian ini merupakan penelitian Observasional analitik menggunakan rancangan Case Control, yang mana variabel dependen dan independen diambil secara bersamaan dalam satu waktu. Penelitian ini dilaksanakan pada bulan Oktober 2011 di Poli Puskesmas Sungkai Kabupaten Banjar. Populasi penelitian adalah semua pasien di Poli Puskesmas Sungkai Kabupaten Banjar, meliputi pasien lama maupun pasien baru. Sampel dibagi dalam 2 kelompok yaitu kelompok kasus dan kelompok kontrol. Kasus adalah pasien dengan diagnosa Hipertensi di Poli Puskesmas Sungkai kabupaten Banjar yang mempunyai kriteria inklusi: a) Berusia diatas 35 tahun, jenis kelamin pria maupun wanita; b). Bersedia ikut penelitian dan bisa berkomunikasi dengan baik; c). Belum pernah konsultasi Gizi. Kriteria eksklusi adalah: a). wanita dengan hipertensi kehamilan; b). Ada diagnosa penyakit lain, seperti DM atau Gagal ginjal. Kontrol adalah pasien poli Puskesmas Sungkai kabupaten Banjar yang memiliki tekanan darah normal, tidak ada penyakit DM, Dislipidemia atau Gagal Ginjal, yang mempunyai kriteria inklusi sebagai berikut: a). Berusia diatas 35 tahun, jenis kelamin pria maupun wanita; b). Bersedia ikut penelitian dan bisa ber- komunikasi dengan baik; c). Belum pernah konsultasi Gizi. Kriteria eksklusi adalah: a. wanita dengan kondisi kehamilan; b). Ada diagnosa penyakit lain, seperti DM atau Gagal ginjal. Besar sampel diambil berdasarkan populasi hipertensi pada bulan penelitian yaitu bulan Oktober 2011 dengan perbandingan $1: 1$ antara sampel Kasus : Kontrol. Pengambilan sampel dilakukan dengan cara purposive sampling, yaitu pengambilan sampel didasarkan pada ciriciri atau pertimbangan tertentu sesuai tujuan penelitian.

Data yang dikumpulkan dalam penelitian berupa data primer yaitu data IMT, Lingkar Pinggang, dan Rasio lingkar pinggang panggul (RLPP) dengan pengukuran antropometri, dan data sekunder yaitu data hipertensi essensial sampel diperoleh dari rekam medik berdasarkan hasil pengukuran tekanan darah yang dilakukan oleh dokter. Data gambaran Umum Puskesmas Sungkai didapatkan dari melihat data laporan tahunan Puskesmas Sungkai Kecamatan Simpang Empat Kabupaten Banjar.

Data diolah dengan membandingkan data berat badan dan data tinggi badan $\left(\mathrm{M}^{2}\right)$ kemudian hasilnya di kategorikan menjadi: Obesitas apabila Indeks Massa Tubuh (IMT) $\geq 30$ dan Tidak obesitas apabila Indeks Massa Tubuh (IMT) < 29,9. Data hasil pengukuran lingkar pinggang kemudian di kategorikan menjadi: Obesitas apabila lingkar pinggang $>0,80$ pada wanita dan $>0,90$ pada laki-laki. Tidak obesitas apabila lingkar pinggang $\leq$ 0,080 pada wanita dan $\leq 0,90$ pada lakilaki. Data Lingkar Pinggang dibagi dengan data lingkar pinggul kemudian di kategorikan menjadi: Obesitas apabila rasio linggar pinggang panggul $>0,8$ pada wanita dan > 0,90 pada laki-laki. Tidak Obesitas apabila rasio linggar pinggang panggul $\leq$ 0,8 pada wanita dan $\leq 0,090$ pada laki-laki. Data Hipertensi pasien yang didapatkan dari pengukuran tekanan darah di kategorikan menjadi: Hipertensi apabila Tekanan Darah $\geq 140 / 90 \mathrm{mmHg}$ danTidak hipertensi apabila Tekanan darah $<140 / 90 \mathrm{mmHg}$. 
Data gambaran umum puskesmas Sungkai yang didapatkan dari laporan tahunan dinarasikan secara diskriptif.

Analisa data dilakukan dengan dua cara yaitu, analisis secara univariat dan bivariat. Analisis univariat terhadap data IMT, lingkar pinggang, rasio lingkar pinggang panggul dan data hipertensi ditabulasi dengan menggunakan tabel distribusi frekuensi dan dinarasikan secara diskriptif. Untuk melihat hubungan antara berbagai indikator obesitas dengan hipertensi dianalisis dengan menggunakan uji Chi-Square dengan tingkat kemaknaan 0,05.

\section{HASIL}

Penelitian ini dilakukan terhadap 60 responden, yang terdiri atas 30 orang kasus dan 30 orang kontrol. Pada setiap kelompok terdiri atas 10 orang responden pria dan 20 orang responden wanita. Hasil penelitian disajikan dengan menggunakan analisis univariat dan bivariat.

\section{Analisis Univariat}

Gambaran status obesitas responden berdasarkan indikator IMT, Lingkar Pinggang, dan Rasio Lingkar Pinggang Panggul dapat dilihat pada tabel 1 .

Tabel 1. Gambaran status obesitas responden berdasarkan indikator IMT, Lingkar Pinggang, dan Rasio Lingkar Pinggang Panggul

\begin{tabular}{|c|c|c|}
\hline Status Obesitas & $\mathrm{N}$ & $\%$ \\
\hline \multicolumn{3}{|l|}{ IMT: } \\
\hline Obesitas & 34 & 56,67 \\
\hline Tidak obesitas & 26 & 43,33 \\
\hline \multicolumn{3}{|l|}{ Lingkar Pinggang: } \\
\hline Obesitas & 35 & 58,34 \\
\hline Tidak obesitas & 25 & 41,66 \\
\hline \multicolumn{3}{|l|}{ Rasio Lingkar Pinggang Panggul: } \\
\hline Obesitas & 41 & 68,34 \\
\hline Tidak obesitas & 19 & 31,66 \\
\hline
\end{tabular}

Tabel 1. Menunjukkan bahwa berdasarkan indikator IMT, responden yang termasuk kategori obesitas berjumlah $56,67 \%$ atau lebih banyak bila disbandingkan dengan tidak obesitas, yaitu 43,33\%. Berdasarkan indikator lingkar pinggang terlihat bahwa lebih dari separuh responden $(58,34 \%)$ termasuk kategori obesitas. Dapat terlihat juga jumlah responden yang mengalami obesitas berdasarkan lingkar pinggang pada kasus lebih banyak dari pada tidak obesitas. Berdasarkan indikator Rasio Lingkar Pinggang Panggul (RLPP), sebanyak $68,3 \%$ responden obesitas dan tidak menderita obesitas sebanyak $31,66 \%$
Pada penilaian status obesitas dengan indikator Rasio Lingkar Pinggang Panggul (RLPP) dapat juga diketahui seseorang termasuk kategori obesitas meskipun pada pengukuran dengan indikator IMT seseorang tidak dikategorikan obesitas, karena pada pengukuran secara RLPP dapat menunjukkan ada atau tidaknya Obesitas Abdominal (sentral) pada seseorang.

\section{Analisis Bivariat}

Hubungan antara status obesitas responden berdasarkan indikator IMT, Lingkar Pinggang, dan Rasio Lingkar Pinggang Panggul terhadap hipertensi dapat dilihat pada tabel 2. 
Tabel 2. Hubungan antara status obesitas responden berdasarkan indikator IMT, Lingkar Pinggang, Rasio Lingkar Pinggang Panggul terhadap Hipertensi

\begin{tabular}{|c|c|c|c|c|c|}
\hline \multirow[t]{2}{*}{ Status Obesitas } & \multicolumn{2}{|c|}{ Tekanan darah } & \multirow[b]{2}{*}{ Jumlah } & \multirow[b]{2}{*}{$\mathrm{p}$-value } & \multirow[b]{2}{*}{ OR } \\
\hline & Hipertensi & Tidak hipertensi & & & \\
\hline \multicolumn{6}{|l|}{ IMT: } \\
\hline Obesitas & 21 & 13 & 34 & \multirow{2}{*}{$0.037 *$} & \multirow{2}{*}{3.1} \\
\hline Tidak obesitas & 9 & 17 & 26 & & \\
\hline \multicolumn{6}{|l|}{ Lingkar Pinggang: } \\
\hline Obesitas & 19 & 16 & 35 & \multirow[t]{2}{*}{0.432} & \multirow[t]{2}{*}{1.51} \\
\hline Tidak obesitas & 11 & 14 & 25 & & \\
\hline \multicolumn{6}{|c|}{ Rasio Lingkar Pinggang Panggul: } \\
\hline Obesitas & 22 & 19 & 41 & \multirow[t]{2}{*}{0.405} & \multirow[t]{2}{*}{1.59} \\
\hline Tidak obesitas & 8 & 11 & 19 & & \\
\hline
\end{tabular}

Tabel 2 dapat diketahui bahwa ada hubungan yang bermakna antara status obesitas berdasarkan indikator IMT terhadap kejadian hipertensi dengan nilai p-value $0,037^{*}$. Penelitian ini menunjukkan bahwa obesitas memiliki kontribusi terhadap terjadinya penyakit hipertensi. Berdasarkan nilai OR, keadaan Obesitas mempunyai kemungkinan 3.1 kali lebih besar untuk menderita hipertensi dibandingkan tidak obesitas.

Berdasarkan hasil uji statistik, pada penelitian ini tidak terdapat hubungan yang bermakna antara status obesitas menurut indikator lingkar pinggang terhadap kejadian hipertensi. Namun demikian keadaan obesitas memiliki kecenderungan 1.5 kali lebih besar untuk menderita hipertensi dibanding tidak obesitas. Demikian juga antara status obesitas berdasarkan indikator rasio lingkar pinggang panggul (RLPP) terhadap kejadian hipertensi tidak terdapat hubungan yang bermakna. Namun, berdasarkan nilai OR dapat diketahui bahwa keadaan Obesitas mempunyai kemungkinan 1,6 kali lebih besar untuk menderita hipertensi dibandingkan tidak obesitas.

\section{PEMBAHASAN}

\section{Indeks Masa Tubuh}

Berdasarkan indikator IMT, responden yang termasuk kategori obesitas blebih banyak bila dibandingkan dengan tidak obesitas. Peningkatan status gizi ini kemungkinan disebabkan adanya peningkatan ke- sejahteraan masyarakat sehingga masyarakat lebih mudah untuk memperoleh sumber makanan tinggi energi (dari makanan sumber karbohidrat, lemak, dan protein), yang berdampak pada peningkatan berat badan. Selain itu juga dsebabkan adanya kesalahan dalam pola makanan yang terutama pada masyarakat adanya kebiasaan mengkonsumsi makanan tinggi gula, dan kebiasaan makanan yang tinggi lemak.

Pengukuran Status gizi dengan menggunakan IMT mempunyai kelebihan dibandingkan dengan metode pengukuran status gizi lainnya, karena IMT dapat menggambarkan keadaan gizi secara keseluruhan karena dilakukan perbandingan antara berat badan dan tinggi badan seseorang.

Akhir-akhir ini indeks massa tubuh menjadi standar medis untuk mengukur kelebihan berat badan dan obesitas. IMT banyak digunakan sebagai pengukuran pilihan oleh sebagian besar peneliti obesitas (Mukhopadhyay, 2005) Indeks massa tubuh (IMT) merupakan indikator status gizi untuk memantau berat badan normal orang dewasa.

Orang-orang yang berada di bawah berat badan normal mempunyai resiko terhadap penyakit infeksi,sementara orang-orang yang berat badannya diatas ukuran normal atau Obesitas mempunyai resiko lebih tinggi terhadap penyakit degeneratif (Supariasa,2002).

\section{Lingkar Pinggang}

Indikator kegemukan dengan mengukur lingkar pinggang adalah cara mudah 
yang bisa dilakukan siapa saja. Karena bisa saja pada pengukuran secara Indeks massa Tubuh seseorang tidak dikategorikan obesitas tetapi dengan pengukuran secara lingkar pinggang ternyata dikategorikan obesitas. Cara ini cukup baik karena mampu menunjukkan seseorang disebut obesitas abdominal (sentral) atau bukan sentral, Gibson (2005) mengemukakan Lingkar pinggang sekarang direkomendasikan sebagai antropometri sederhana untuk menaksir lemak abdominal. Hal tersebut yang menjadi pertimbangan dalam pengukuran antropometri yang praktis.

Banyaknya lemak di dalam perut menunjukkan ada perubahan metabolisme termasuk daya tahan terhadap insulin dan meningkatnya produksi asam lemak bebas dibanding dengan banyaknya lemak di bawah kulit atau pada kaki dan tangan (Supariasa, 2002). Pada saat tubuh tidak mendapatkan energi dari makanan (eksogen) maka lemak dalam rongga perut akan dipecah menjadi asam lemak dan gliserol yang kemudian keduanya masuk ke sirkulasi darah yang dapat mempengaruhi kadar lipid darah (Wiramihardja, 2004).

\section{Rasio Lingkar Pinggang Panggul}

Rasio Lingkar Pinggang Panggul (RLPP) adalah rasio lingkar pinggang terhadap lingkar panggul adalah salah satu indeks antropometri yang menunjukkan status kegemukan, terutama central obesity atau $a b$ domen adiposity (Depkes RI, 2006). Rasio lingkar pinggang dan pinggul (RLPP) menunjukkan jumlah lemak di perut. Semakin tinggi rasio, semakin banyak lemak (Tjay T. H. dan Kirana R.,2007).

\section{Hubungan Status Obesitas berdasarkan In- dikator IMT Terhadap Hipertensi}

Adanya hubungan antara obesitas dengan hipertensi ini disebabkan juga adanya faktor kebiasaan pola makan yang kurang baik yang ada di masyarakat tempat diadakannya penelitian ini yaitu kebiasaan mengkonsumsi makanan tinggi lemak, tinggi gula dan juga penggunakan bahan makanan ataupun sumber natrium yang berlebih. Obesitas dipengaruhi oleh karena kurangnya aktifitas fisik/olahraga sehingga semakin meningkatkankan resiko terjadinya hipertensi karena Indeks Massa Tubuh yang berlebih.

IMT merupakan indikator pengukuran obesitas yang dapat menggambarkan jumlah lemak tubuh. Status gizi responden banyak yang mengalami obesitas. Peningkatan status gizi ini kemungkinan disebabkan adanya peningkatan kesejahteraan masyarakat sehingga masyarakat lebih mudah untuk memperoleh sumber makanan tinggi protein, lemak dan karbohidrat yang berdampak pada peningkatan berat badan.

Obesitas menyebabkan meningkatnya resiko yang lebih tinggi terhadap terjadinya penyakit hipertensi hal ini disebabkan penumpukan lemak yang berlebihan di seluruh jaringan tubuh akan mengakibatkan tingginya kadar LDL, rendahnya HDL dan menyebabkan pengendapan kolesterol di pembuluh darah yang dapat berakibat langsung pada terjadinya penyakit hipertensi.

Penelitian ini sejalan dengan penelitian Shils (2006) dalam suatu penelitian Cohort pada sekitar 5000 orang Britania pada minggu yang sama yang menunjukkan bahwa tekanan darah pada usia 36 tahun progresif lebih tinggi pada IMT diatas 26. Kenaikan setiap $3 \mathrm{mmHg}$ tekanan diastolik dapat dilakukan dengan mengurangi $10 \mathrm{~kg}$ berat badan Hasil penelitian yang sama dikemukakan juga oleh Katz et al. (2008) yang menyatakan bahwa dengan menjaga IMT normal 18.5 sampai 24.9 $\mathrm{kg} / \mathrm{m}^{2}$ dapat mengurangi tekanan sistolik 5 - $20 \mathrm{mmHg} / 10 \mathrm{~kg}$. Penelitian Zafar S., et al (2007) juga didapatkan adanya korelasi positif antara IMT dan SBP (Pria $\mathrm{r}=$ $0.356, p<0.0001$. Wanita $r=0.412$ ) dan IMT dan DBP (Pria $r=0.396$, Wanita $r=$ 0.412). $\mathrm{p}<0.000$

Data dari NHANES III menunjukkan bahwa prevalensi hipertensi meningkat progresif dengan tingginya IMT pada pria dan wanita. Pada penelitian cross sectional 
pada lebih dari 10.000 pria dan wanita, menunjukkan hubungan langsung antara IMT dan hipertensi. Prevalensi hipertensi dengan IMT $\geq 30$ adalah $38,4 \%$ pada pria dan $32,2 \%$ pada wanita berbanding $18,2 \%$ pada pria dan $16,5 \%$ pada wanita dengan IMT < 25, RR 2,1 pada pria dan 1,9 pada wanita (Xafier F., 2003).

\section{Hubungan Obesitas Berdasarkan indikator Lingkar Pinggang Terhadap Hipertensi}

Adanya perbedaan hasil penelitian ini dapat disebabkan oleh karena pada kelompok kontrol juga lebih banyak responden yang memiliki status obesitas berdasarkan lingkar pinggang dibanding dengan yang tidak obesitas, selain itu juga karena adanya perbedaan cara pengukuran lingkar pinggang. Selain itu juga secara teoritis banyaknya lemak diperut dapat meningkatkan produksi asam lemak bebas yang kemudian akan dipecah menjadi asam lemak dan gliserol akan tetapi pada responden penelitian ini tidak terjadi peningkatan kadar LDL dan penurunan kadar HDL serta tidak terjadi pengendapan kolesterol di pembuluh darah sehingga tidak menyebabkan terjadinya penyakit hipertensi

Meskipun berdasarkan hasil uji statistik tidak adanya hubungan yang bermakna antara Lingkar pinggang dengan penyakit hipertensi, akan tetapi berdasarkan perhitungan OR dapat diketahui bahwa adanya kemungkinan yaitu 1,5 kali lebih besar penderita obesitas berdasarkan Lingkar Pinggang untuk menderita hipertensi dibandingkan dengan yang tidak obesitas .

Obesitas sentral memiliki hubungan yang sangat erat dengan gangguan metabolik dan sering disertai dengan munculnya faktor risiko metabolik yang dapat memicu terjadinya berbagai komplikasi diantaranya yaitu peningkatan tekanan darah (Poirier,2006). Pada penelitian yang dilakukan oleh Poirier P., et al, pengukuran lingkar pinggang dilakukan pada panjang lingkar terkecil di badan, sedangkan pada penelitian yang dilakukan ini lingkar pinggang diukur dengan pengukuran panjang lingkar daerah antara tulang rusuk paling bawah dengan puncak iliaka melewati secara horizontal umbilikus/pusar. Lingkar pinggul sendiri juga tidak bisa menggambarkan efek dari penumpukan lemak. Lingkar pinggul dapat menunjukkan hubungan dengan suatu penyakit tergantung pada sejumlah penyesuaian untuk total ukuran tubuh seperti IMT.

Hasil penelitian ini sejalan dengan penelitian yang dilakukan oleh Tri Melia Hapasari (2009) yang melakukan penelitian Hubungan Lingkar Pinggang dan Rasio Lingkar Pinggang Panggul (RLPP) dengan tekanan darah pada wanita menopause di kelurahan Tlogosari kecamatan Pedurungan Semarang, dengan menggunakan uji statistic Rank Sperman. Hasil Penelitian tersebut diatas menunjukkan bahwa $77 \%$ mempunyai Lingkar Pinggang lebih dari $80 \mathrm{~cm}$ sebanyak $81 \%$, mengalami hipertensi sistolik $67 \%$ Hipertensi diastolic $52 \%$. Hasil analisa sebelum dikontrol variabel pengganggu asupan lemak, Natrium dan serat menunjukkan ada hubungan dengan hipertensi, Koefiesien berubah setelah dikontrol variable pengganggu menjadi tidak ada hubungan antara Lingkar Pinggang dengan hipertensi sistolik $(r=$ $0,267$ dan $\mathrm{p}=0,77)$ dan diastolic $(\mathrm{r}=$ 0,259 dan $\mathrm{p}=0,086$ )

\section{Hubungan Status Obesitas Berdasarkan Indikator RLPP Terhadap Hipertensi}

Kelebihan lemak tubuh terutama lemak abdomen, berhubungan dengan tekanan darah dan prevalensi hipertensi (Budiman, 1999). Menurut Purba (2003) menyatakan bahwa makin tinggi rasio lingkar pinggang dan lingkar pinggul (RLPP), maka risiko terjadinya hipertensi makin tinggi.

Lemak yang tertimbun di rongga perut merupakan sumber energi dari dalam tubuh. Lemak di rongga perut diuraikan menjadi asam lemak dan gliserol yang kemudian kedua-duanya masuk kedalam sirkulasi darah. Asam lemak yang masuk kedalam sirkulasi darah me- 
rupakan tambahan asupan lemak yang dapat mempengaruhi kadar lemak darah, yaitu trigliserida, kolesterol total, kolesterol low density lipoprotein (LDL) dan kolesterol high density lipoprotein (HDL). Perubahan kadar lemak dalam darah ini dapat menyebabkan penyakit dislipidemia ( Wiramihardja, 2004)

Dislipidemia merupakan faktor resiko untuk mengidap hipertensi, serangan jantung dan stroke. Kolesterol LDL merupakan kolesterol jahat yang mengangkut kolesterol dari hati keseluruh organ. Kadar kolesterol total dan kolesterol LDL darah yang tinggi berpotensi untuk mengendapkan kolesterol pada dinding pembuluh darah sehingga aliran darah menyempit yang mengakibatkan tekanan darah meningkat

Meskipun demikian pada responden penelitian ini tidak terjadi hal yang demikian kadar kolesterol total dan LDL darah kemungkinan masih berada dalam batas normal disertai dengan kadar HDL darah yang masih tinggi sehingga tidak terjadi pengendapan di pembuluh darah menyebabkan tidak terjadinya penyakit hipertensi, akan tetapi dilihat dari nilai OR yang lebih tinggi maka tidak menutup kemungkinan suatu saat akan tetap terjadinya penyakit Hipertensi.

Kejadian hipertensi selain dipengaruhi faktor RLPP yang nilainya lebih dari normal, juga di pengaruhi oleh faktor genetik, aktivitas fisik, merokok, jenis kelamin, diet yang tidak seimbang dan peningkatan usia. Faktor genetik menurut Karyadi (2002), dapat mempertinggi risiko kejadian hipertensi, terutama hipertensi primer (esensial), faktor genetik juga dipengaruhi faktor lingkungan.

Jumlah sampel yang memiliki rasio lingkar pinggang dengan lingkar pinggul tidak obesitas jumlahnya sedikit dibandingkan dengan sampel yang memiliki rasio lingkar pinggang dengan lingkar pinggulnya obesitas atau lebih, hal tersebut mungkin berpengaruh terhadap hasil uji statistik, sehingga diperoleh tidak terdapat hubungan yang bermakna. Hasil penelitian ini sejalan dengan penelitian yang dilakukan oleh Tri Melia Hapasari (2009) yang menunjukkan bahwa $77 \%$ mempunyai rasio lingkar pinggang panggul (RLPP) lebih dari 0,85 sebanyak $44 \%$, mengalami hipertensi sistolik $67 \%$ hipertensi diastolic 52\%. Hasil analisa sebelum dikontrol variabel pengganggu asupan lemak, natrium dan serat menunjukkan ada hubungan dengan hipertensi, Koefiesien berubah setelah dikontrol variabel pengganggu menjadi tidak ada hubungan antara rasio lingkar pinggang panggul (RLPP) dengan hiupertensi $(r=0,259$ dan $\mathrm{p}=0,063$ )

\section{KESIMPULAN}

Dari hasil penelitian dapat dikemukan kesimpulan bahwa ada hubungan yang bermakna antara status obesitas berdasarkan indeks IMT terhadap Hipertensi di Poli Puskesmas Sungkai Kabupaten Banjar. Tidak ada hubungan antara status obesitas berdasarkan indeks Lingkar Pinggang terhadap Hipertensi, namun terdapat kemungkinan keadaan obesitas 1,5 kali lebih besar untuk menderita hipertensi dari pada tidak obesitas. Demikian pula, tidak ada hubungan antara status obesitas berdasarkan indeks Rasio Lingkar Pinggang Panggul (RLPP) terhadap Hipertensi, tetapi keadaan obesitas memiliki kecenderungan 1,6 kali lebih besar untuk menderita hipertensi dibandingkan tidak obesitas.

\section{SARAN}

Disarankan bagi penderita hipertensi untuk mempertahankan berat badan dalam batas normal untuk mencegah terjadinya komplikasi penyakit lain. Bagi penderita obesitas yang belum menderita penyakit hipertensi disarankan untuk mengatur pola makan yang benar yaitu mengurangi makanan tinggi lemak, tinggi gula dan makan sumber natrium. Pelayanan bagi pasien penderita hipertensi agar dapat diberikan secara kolaborasi penanganan pengobatan dan juga pelayanan konsultasi gizi bagi pasien untuk mencegah terjadinya komplikasi penyakit lain. 
Penelitian lanjutan variabel penyebab hipertensi lainnya antara lain faktor genetik, aktifitas fisik, merokok, jenis kelamin, di-

\section{DAFTAR KEPUSTAKAAN}

Beevers D.G. 2002. Seri Kesehatan, Bimbingan Dokter Pada Tekanan Darah. Ed Ayodya L. Ryadi. Dian Rakyat, Jakarta.

Depkes RI.2009.Laporan Hasil Riset Kesehatan Dasar Indonesia Tahun 2007. Jakarta

Erlina S.2008.Hubungan Antara Obesitas dengan Tekanan Darah Tinggi pada Ibu Rumah Tangga di Kelurahan Kartasura. Tersedia dalam < http://www/giziu>.diakses tanggal 1 Juni 2011

Karyadi E. 2002. Intisari Hidup Bersama Penyakit Hipertensi, Asam Urat dan Jantung Koroner. Gramedia. Jakarta.

Katz, David L., Friedman \& C. S. Rachel. 2008. Nutrition in Clinical Practice : A comprehensive, Evidence-Based Manual For The Practitioner $2^{\text {nd }}$ Edition . Tersedia dalam $<$ http://blog.e-healthgr $>$,Lippincott Willims $\&$ Wilkins, Connecticut,. Diakses 22 Januari 2009

Hapsari,Melia T.2009. Hubungan Lingkar Pinggang dan Rasio Lingkar pinggang panggul dengan tekanan Darah pada wanita Menopause.Tersedia dalam $<$ http ://.fkm.undip.ac.id >.Diakses 13 Pebruari 2011

Poirier P., Chilen T.D., Bray G.A., Hong Y. S.Judith., F. Sterm, Pi Xafier. Sunyer dan Eckel R.H. 2006. Obesity And Cardiovascular Disease : Patophysiology, Evaluation, and Effect of Weight Loss : American Heart Association Scientific Statement on Nutrition, Physical Activity, and Metabolism.Circulation : 113:898-918. Tersedia < $\underline{\text { http:// }}$ et yang tidak seimbang dan peningkatan usia.

www.who.int/ cardiovaskular disease/. Diakses 11 Desember 2008.

Purba, Martalena Br. 2003. Obesity In the elderly: Focus On Insulin Resistence And High Blood Presure. Proseding National Obesity Symposium II. ISSO: Surabaya.19-20 Juli 2003. 63-68.

Sanif E. Hipertensi dan Obesitas. Tersedia dalam <http://www. jantung hipertensi. com>. Diakses 7 Juni 2011.

Shils M.E., Moshe Shike, A. Catharine Ross, Benjamin C. And Robert. J.C. 2006. Modern Nutrition in Health and Disease. $10^{\text {th }} \overline{\text { Edition, }}$ Lipincott Williams \& Wilkins, North Carolina. Tersedia dalam < http://blog.ehealthgr. Kedokteran buku gratis. Diakses 27 Januari 2009.

Supariasa I.D.N., Bachyar Bakri dan Ibnu Fajar. 2002. Penilaian Status Gizi. EGC, Jakarta.

Xafier F. 2003. Clinical Guidelines on The Identification, Evaluation And Treatment of Overweight and Obesity In Adults.The Evidence Report. National Institute of Health, NIH Publication No. 98 - 4083 Tersedia dalam< http://blog.e-healthgr $>$. diakses 06 Juni 2011.

Zafar S., Israr ul Haque, Anjum R.B., Huda G.M., Fuad S., Ammed ur Rehman and Nusrat U. C., 2007. Relationship of Body Mass Index and Waist to Hip Ratio Measurement with Hypertension in Young Adult Medical Students. Pakistan Journal of Medical Sciences published by Proffesional Medical Publication Volume 23 July - September 2007 No. 4, ISSN 1681-715X. 574 - 579. 